\title{
The Determinants Of Capital Flight: Evidence From MENA Countries
}

\author{
Nedal A. Al-Fayoumi, The University of Jordan, Jordan \\ Marwan S. AlZoubi, Central Bank of Jordan, Jordan \\ Bana M. Abuzayed, The German Jordanian University, Jordan
}

\begin{abstract}
This paper examines the determinants of capital flight in seven Middle East and North Africa (MENA) countries during the period of 1981-2008. The results are robust to four econometrics techniques: Ordinary least Squares, Fixed effects, Random Effects, and Seemingly Unrelated Regression Model. The empirical findings indicate that the capital flight in MENA countries is driven mainly by lag capital flight, external debt, foreign direct investment, real GDP growth rate and uncertainty. Based on these results, the paper recommends that governments in these countries should manage their external debt efficiently, and stabilize their monetary and macroeconomic policies in order to staunch capital flight.
\end{abstract}

Keywords: Capital Flight; MENA; Panel Data; External Debt; Inflation

\section{INTRODUCTION}

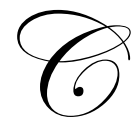

apital Flight has been an important issue since early 1980s in developing countries. A massive amount of capital left these countries during the last three decades (Alam and Quazi, 2003). Capital flight can be defined as the movement of capital out from a resource-scarce developing country to avoid social control. It is measured as net unrecorded capital outflow or the residual between officially recorded sources and recorded uses of funds (Beja, 2006). Many developing countries concern with capital flight phenomenon because of its deleterious impact on economic growth and welfare, macroeconomic stability, income distribution, illegal activities and other social development matters (Zheng and Tang, 2009).

The theoretical explanation of capital flight mainly focuses on portfolio choice decisions. From this perspective, profit maximizing investors will decide to invest outside the country when risk adjusted returns abroad are higher. Therefore, capital flight is seen as a response to changes to an individual's portfolio bundle arising from factors such as the fear of political and economic uncertainty (Mohamed and Finnoff, 2004). Empirically, several factors were cited as contributors to capital flight. Many scholars believe that external borrowing, short-term inflow of capital and financial aid fuel capital flight (see Cerra et al. 2005; Chipalkatti and Rishi, 2002; Beja, 2006; Ndikumana and Boyce, 2008). However, others argue that factors such as real GDP growth rate, foreign direct investment, interest rate differential, inflation rate, exchange rate, and uncertainty also have an important role (see, Hermes and Lensink 2001; Ndikumana and Boyce, 2003; Fedderke and Liu, 2002; Ljungwall and Wang, 2008). This difference in emphasis on the drivers of capital flight has not been resolved by empirical research, as each approach enjoys some empirical support (Kutan et al. 2009).

This study contributes to the literature by investigating the factors affecting capital flight in the Middle East and North Africa (MENA) region. Countries included are Jordan, Syria, Algeria, Morocco, Egypt, Turkey, and Tunisia during the period 1981-2008. Obviously, the region is highly diversified but less integrated. Most countries suffer from high unemployment rates and budget deficits, low per capita incomes, high external borrowings and income inequalities (Almansour, 2008). We can consider MENA countries as an interesting sample from which to draw some inferences about the determinants of capital flight because most these countries witnessed serious steps of economic and institutional reforms and structural changes in order to enhance their economic development. These reforms may quickly alter the costs of moving capital abroad; as did a very rapid opening to the world economy (see 
Brada, et al. 2009). Additionally, most of previous research concentrated on the causes of capital flight in SubSaharan Africa, South East Asia and Latin America and a little attention has been given to examine this issue in MENA countries. Therefore, understanding the forces, dynamics, behavior and consequences of capital movement can help policy makers formulate policies that can have a significant impact on the development process in the region (Almansour, 2008).

The remaining of the paper is organized as follows: sections two and three discuss the definition and measurement of capital flight. Section four reviews the literature. Section five introduces the empirical model. Section six presents the results and the final section offers summary and conclusions.

\section{CAPITAL FLIGHT DEFINITION}

One of the best definitions of capital flight is the unrecorded private capital outflows which could be legal and useful to the economy or illegal and harmful to the economy. Buiter and Szegvari (2002) define capital flight as the outflow of capital by rational investors searching for better risk-return trade-offs and portfolio diversification. Capital flight can be triggered be illegal actions to hide money laundering activities such as drug distribution (Brada et al., 2009).

Lessard and Williamson (1987) contend that capital flight is caused by the fear of capital loss domestically due to risks of expropriation, exchange rate depreciation, capital controls, taxation and financial repression. If capital is leaving the country for better risk- return opportunities then it will not be classified as capital flight, but a rational outflow of funds.

Beja (2007) emphasizes that short term inflows of capital and external borrowing in developing countries are the main causes of capital flight. Capital flight is defined as the private sector's outflow of capital from developing countries with scarce reserves of foreign exchange. Outflow of capital follows a revolving fashion in that external borrowing is transformed into capital flight due the increased debt service and therefore increased default risk.

Beja (2007) points out that there are direct and indirect factors that affect capital flight and external borrowing. The direct effect means that external borrowing is transformed into capital flight sometimes instantaneously. Other times, the process takes time because debt is accumulated and its services becomes larger and larger with increased default risk.

The indirect effect occurs due to macroeconomic mismanagement and policy mistakes which affect both external borrowing and capital flight at the same time, but none of them is causing the other. For example, McKinnon (1991) points out that implementing premature deregulation and financial liberalization strategy may result in more debt and capital flight.

\section{CAPITAL FLIGHT MEASUREMENT}

There are several methods used in the literature to measure capital flight. Some of them are direct, while others are indirect. The Residual measure introduced by the World Bank (1985) is the most popular measure and it relies on the indirect definition of capital flight.

Capital flight represents the difference between sources of capital (new external borrowing, new inflow of foreign direct investment, and exports of goods and services) and uses of capital (outflow of foreign direct investment, imports of goods and services, and official foreign reserves change). Mathematically, capital flight can be written as follows:

$C F R=C X B+N F D I-C A D-C O F R$

Where, 
CFR $=$ Capital Flight (residual measure)

$\mathrm{CXB}=$ Change in external borrowing

NFDI $=$ Net foreign direct investment

$\mathrm{CAD}=$ Current account deficit

$\mathrm{COFR}=$ Change in official foreign reserves

This measure does not differentiate between regular and lawful outflow of capital searching for better riskreturn tradeoffs from hot money transfers of capital searching for speculative opportunities.

Another indirect measure introduced by Morgan Guaranty Trust Company (1986), the private claim measure, assumes that the banking system is not involved in capital flight. It substracts the change in short - term foreign assets of the banking system from the World Bank equation, as follows:

$C F P C=C X B+N F D I-C A D-C O F R-C B S F A$

Where,

CFPC $=$ Capital flight (private claim)

CBSFA $=$ Change in short - term banking system foreign assets

This measure assumes that banks do not participate in capital flight given that they are well organized institutions that are under the supervision of central banks. In many countries, this is considered a valid assumption while in others; it is considered a strong assumption.

The balance of payments measure introduced by Cudington (1986) defines capital flight as short-term capital outflow rather than total outflow of capital by the private sector. Cuddington measure can be calculated as follows:

$C F C=N B S C+E \& O$

Where,

$\mathrm{CFC}=$ Capital flight (Cuddington)

NBSC $=$ Non-bank short-term capital outflow

$\mathrm{E} \& \mathrm{O}=$ Balance of payments errors and omissions

It is implied that banks cannot get involved in capital flight activities especially because those organizations are supervised by central banks. Another assumption is that errors and omissions represent unrecorded capital flows rather than discrepancies arising from the measurement errors of variables included in the balance of payment. Also, this measure assumes that capital flight excludes long term investment. That is, it excludes any capital outflows chasing long-term investment opportunities.

\section{LITERATURE REVIEW}

A large number of research papers studied the causes of capital flight in developing countries. Most of these studies present evidence that macroeconomic variables such as external borrowing, foreign direct investment, interest rate differential, inflation rates and taxes are important determinates of capital flight.

In their seminal paper, Ndikumana and Boyce (2003) investigate the determinants of capital flight from 30 sub-Saharan African countries, including 24 countries classified as severely indebted low-income countries, for 1970-96. Their econometric analysis reveals that external borrowing is positively and significantly related to capital flight, suggesting that to a large extent capital flight is debt-fueled. Capital flight also exhibits a high degree of persistence in the sense that past capital flight is correlated with current and future capital flight. 
In nother study, Beja (2007) examines the effect of external borrowing on capital flight in Indonesia, Malaysia and Thailand. The results show that large capital inflows and outflows follow a revolving door mechanism. This implies that external borrowing provides fuel and motive for capital flight. More debt increases debt service and risk and therefore causes capital flight. Capital left those countries may return in the form of foreign investment or debts, and hence follow a revolving mechanism. The findings also indicate that good indicators of economic growth and sufficient international reserves discourage external borrowings and capital flight.

The importance of external borrowing in explaining changes of capital flight is also found in Ljungwall and Wang (2008). Using balance of payments data over the period 1993-2003 in China, the authors study several factors believed to be contributors to capital flight. The result obtained from China is similar to the Latin American experience in that external borrowing fuels capital flight (Cuddington 1986, Mckinnon 1991).The insignificant factors are the exchange rate and the interest rate. Both are not market determined in china.

Another strand of the literature in this area focused on measuring the magnitude of capital flight. For example, Ndikumana and Boyce (2001) present estimates of capital flight from 25 low-income sub-Saharan African countries in the period 1970 to 1996 . Taking capital flight as a measure of private external assets, and calculating net external assets as private external assets minus public external debts, sub-Saharan Africa thus appears to be a net creditor vis-à-vis the rest of the world. Moghadam et al. (2003) examine definitions and different approaches to measuring capital flight and develops a refined residual approach to the measurement of capital flight. Estimates of capital flight from the East Asian emerging countries for the 1987 through 1997 period are then calculated and reported. The authors conclude that greater openness of both private and public sector accounting practices is required to mitigate the disruptive impact of capital flight on the emerging economies. Zheng and Tang (2009) applied an improved measure of capital flight in contrast to the traditional measure. Capital flight is measured against money aggregates rather than against GDP because capital is a financial resource not a real resource. The paper finds that capital flight is more serious in financially less developed Asian countries than has been suggested by previous research papers.

Finally, it is worth noting that a number of papers attempt to bring up more robust results regard the determinants of capital flight by applying different econometrics techniques. For example, Chipalkatti and Rishi, (2002) Utilized a simultaneous equation model to examine the association between capital flight and external debt in the Indian economy during the period 1971-1997. The paper confirms the existence of a financial revolving door relationship between the two endogenous variables.

Alam and Quazi (2003) study the determinants of capital flight in Bangladesh during 1973-1999 by applying the bounds testing and autoregressive distrubted lag, a new cointegration technique developed by Pesaran et al. in (2001). Findings indicate that political instability is the most important factor affecting capital flight. Other factors that are proved to be significant include corporate income taxes, higher real interest rate differentials and lower GDP growth rates. The exceptional importance of macroeconomic fundamentals is also reported by Harrigan et al. (2002) for Malaysia during 1970-1996. Results reveal that real GDP growth and direct foreign investments are associated with a decrease in capital flight while currency depreciation and external borrowing are associated with an increase in capital flight. Cheung and Qian (2010) examine the empirical determinants of China's capital flight during the period 1999-2008. In addition to the covered interest differential, their empirical exercise includes a rather exhaustive list of macroeconomic variables and a few institutional factors. Overall, the regression analysis shows that China's capital flight is quite well explained by its own history and covered interest differentials. The other possible determinants offer relatively small additional explanatory power.

\section{METHODOLOGY}

\subsection{The Model}

The theory does not offer a sharp way of determining a priori which independent variables should be included when we examine that factors that affect the variation in the capital flight (Ndikumana and Boyce, 2003). Therefore, we follow the literature and examine the most important variables that have been considered. It appears that real effective exchange rate, real GDP growth, foreign direct investment, external debt, the rate of return 
differentials, uncertainty, and inflation do have a statistically significant impact on capital flight in previous studies (see Ndikumana and Boyce, 2003; Hermes and Lensink, 2001; Ljungwall and Wang, 2008; Wang et al. 2009).

Consistent with the above discussion regarding the various capital flight determinants, the Model specification can be represented by the following equation:

$$
\begin{aligned}
K_{i t}= & \alpha+\beta_{1} K F i_{t-1 \cdot 1}+\beta_{2} E D_{i t}+\beta_{3} G R_{i t}+\beta_{4} U N C_{i t}+\beta_{5} F D I_{i t}+\beta_{6} R E E R_{i t} \\
& \beta_{7} I N F_{i t}+\beta_{8} I N R_{i t}+\varepsilon_{i t}
\end{aligned}
$$

Where, for a country $i$ at time $t$,

$K F_{t-1}=$ capital flight for year $t-1 ; \mathrm{ED}=$ external debt; rate; GR $=$ real GDP growth; UNC $=$ uncertainty; FDI $=$ net foreign direct investment; REER = real effective exchange; INF = inflation rate; INR $=$ interest rate differentials; $\varepsilon=$ error term.

\subsection{Rationale of the model}

- Dependent Variable

Capital Flight $(K F)$ is expressed as a percentage of GDP. We use the World Bank method (1985), which is considered to be the broadest estimate of capital flight in order to minimize potential biases in narrower measures (see Le and Rishi, 2006).

- $\quad$ Independent Variables

Past Capital Flight $\left(K F_{t-1}\right)$ : several empirical studies (eg., Mikkelsen, 1991; Vos, 1992) have reported a positive correlation between past capital flight and current capital flight, suggesting that capital flight tends to persist over time (see Ndikumana and Boyce, 2003).

External Debt $(E D)$ is measured as change in external debt divided by GDP. For developing countries, an increase in external debt usually brings about inflationary financing, which is equal to impose an "inflation tax" on domestic residents (Ljungwall and Wang, 2008). In order to avoid this situation, people will have a motivation to investment abroad. Hence, we assume a positive relationship between external debt and capital flight.

Real GDP Growth (GR): following Mikkelsen (1991) and Harrigan et al. (2002), we use the real GDP growth rate as a measure the macroeconomic performance of the country. A negative relationship is expected between capital flight and real GDP growth rate (Ndikumana and Boyce 2003). Higher economic growth is a signal of higher expected returns on domestic investment, which induces further domestic investment and thus reduces capital flight (Ndikumana and Boyce 2008).

Uncertainty (UNC): an unstable macroeconomic environment increases uncertainty over expected returns to domestic capital, which reduces incentives for investing domestically, thus increasing capital flight (Ndikumana and Boyce 2008). We measure the macroeconomic uncertainty by calculating the deviation of GDP from its threeyear moving average.

Foreign Direct Investment (FDI) is measured as FDI deflated by GDP. We include this variable in the model in order to see if FDI facilitate or reduce capital flight (see Le and Rishi, 2006).

Real Effective Exchange Rate (REER): the presence of exchange rate policies that imply short-run real appreciation of domestic currency can lead to capital outflows as domestic investors looking for avoiding capital losses when the overvaluation is corrected (Harrigan et al., 2002). In this study, we will use the percentage change in the real effective exchange rate as a measure of exchange rate overvaluation. 
Inflation (INF) means an increase in the average level of general prices in the economy. We measure inflation as the percentage change in the consumer price index between two years. A positive relationship is expected between inflation and capital flight because a high expected inflation would result in deterioration of the value of domestic assets compared to foreign assets.

Interest Rate Differentials (INR) is estimated as the domestic real interest rate minus the US risk free rate. The coefficient of this variable is expected to have a negative sign because a higher domestic return rate compared to the foreign return rate would result in capital reversal (Le and Rishi, 2006).

\subsection{Data and Estimation}

The dependent and independent variables were constructed using the data from International Financial Statistics (IFS) issued by International Monetary Fund, World Bank Economic Indicators (WEI) and UNCTAD data base. The regression analysis was carried out using annual panel data from a sample of MENA countries. The panel data used to estimate this model consist of $i$ cross-sectional units where $i=1,2, \ldots, 7$ for the seven countries (Jordan, Syria, Algeria, Morocco, Egypt, Turkey, and Tunisia) observed at each of $t$ time periods, $t=1,2, \ldots, 28$ (1981 through 2008). Only the data for these seven countries were included in the regression models because part of the data was not available for other MENA countries. Additionally, we didn't include the Gulf Cooperation Council (GCC) countries in our sample because of their economic specialty. Including these countries in our sample will make it heterogeneous.

When we estimate the study model (Eq. 4), we pay due attention to potential causes of biases in the estimates, which especially arise in the context of pooled data using Ordinary Least Squares (OLS). Consequently, the regression model is also estimated based on two different econometrics techniques: Panel Data Analysis and Seemingly Unrelated Regression (SUR).

Under panel estimation model, we consider two types of model specification for controlling the individual firm effects (Bunkanwanicha et al. 2008): (i) fixed-effects model which takes individual firm effects as constant, and (ii) random-effects model which treat the individual firm effects as disturbance. The distinction between fixed and random effects models is an erroneous interpretation (see Al-Fayoumi and Abuzayed, 2009).

Separate OLS, fixed and random effects estimation may ignore the possible relatedness of the equations errors. These estimators assume that the errors across our countries equations are uncorrelated, and thus the offdiagonal elements of the covariance matrix are zero. Therefore, we apply SUR model in order to consider the fact that the errors for these equations may be contemporaneously (in the same time period) correlated, and thus the offdiagonal elements may be non-zero (Ralhan, 2006).

\section{RESULTS}

This section presents the results of empirical analysis based on OLS, Fixed Effects, Random Effects, and SURE models in order to determine the factors affecting capital flight in a sample of MENA countries over the period 1981-2008. Table 1 presents the results of the four models.

Under four regressions, the estimated coefficients on lagged capital flight $\left(K F_{t-1}\right)$ are positive and significant at about 5\% level. This result indicates that there is a tendency for capital flight to persist over time and consistent with the explanation presented by Ndikumana and Boyce (2008) who argue that the significant $K F_{t-1}$ variable may reflect a habit-formation effect, as private actors gain experience in capital flight operations. It may also reflect a contagion effect, as capital flight corrodes the legitimacy of capital controls, particularly if the flight capitalists include government authorities. 
Table 1

The Determinants of Capital Flight for MENA Countries (1981-2008)

\begin{tabular}{|c|c|c|c|c|}
\hline & OIS & & DF & SUD \\
\hline$K F_{t-1}$ & $\begin{array}{c}0.154 * * \\
(2.507)\end{array}$ & $\begin{array}{c}0.158 * * \\
(2.567)\end{array}$ & $\begin{array}{c}0.156 * * \\
(2.562)\end{array}$ & $\begin{array}{c}0.154 * * \\
(2.572)\end{array}$ \\
\hline$E D$ & $\begin{array}{c}0.959 * * * \\
(15.150)\end{array}$ & $\begin{array}{c}0.988 * * * \\
(15.563)\end{array}$ & $\begin{array}{c}0.969 * * * \\
(15.424)\end{array}$ & $\begin{array}{r}0.959 * * * \\
(15.539) \\
\end{array}$ \\
\hline GR & $\begin{array}{l}-0.133^{*} \\
(-1.941) \\
\end{array}$ & $\begin{array}{l}-0.111^{*} \\
(-1.795) \\
\end{array}$ & $\begin{array}{l}-0.126^{*} \\
(-1.840) \\
\end{array}$ & $\begin{array}{l}-0.133^{*} \\
(-1.850) \\
\end{array}$ \\
\hline UNC & $\begin{array}{c}0.487 * * * \\
(3.460)\end{array}$ & $\begin{array}{c}0.506 * * * \\
(3.316)\end{array}$ & $\begin{array}{c}0.493 * * * \\
(3.480) \\
\end{array}$ & $\begin{array}{c}0.487 * * * \\
(3.549) \\
\end{array}$ \\
\hline FDI & $\begin{array}{c}0.873 * * * \\
(11.287) \\
\end{array}$ & $\begin{array}{c}0.896 * * * \\
(7.910)\end{array}$ & $\begin{array}{c}0.877 * * * \\
(10.843)\end{array}$ & $\begin{array}{c}0.873 * * * \\
(11.579) \\
\end{array}$ \\
\hline REER & $\begin{array}{c}-0.295 \\
(-0.675) \\
\end{array}$ & $\begin{array}{c}-0.239 \\
(-0.552) \\
\end{array}$ & $\begin{array}{c}-0.278 \\
(-0.643) \\
\end{array}$ & $\begin{array}{c}-0.295 \\
(-0.693) \\
\end{array}$ \\
\hline INF & $\begin{array}{c}-0.258 \\
(-0.306)\end{array}$ & $\begin{array}{c}-0.467 \\
(-0.546) \\
\end{array}$ & $\begin{array}{c}-0.332 \\
(-0.396) \\
\end{array}$ & $\begin{array}{c}-0.258 \\
(-0.314) \\
\end{array}$ \\
\hline INR & $\begin{array}{c}-0.510 \\
(-0.707) \\
\end{array}$ & $\begin{array}{c}-0.138 \\
(-0.156) \\
\end{array}$ & $\begin{array}{c}-0.384 \\
(-0.521) \\
\end{array}$ & $\begin{array}{c}-0.510 \\
(-0.725) \\
\end{array}$ \\
\hline Adj. $R^{2}$ & $86.27 \%$ & $86.58 \%$ & - & $86.27 \%$ \\
\hline F-Stat. & 143.15 & 73.97 & - & 143.15 \\
\hline Sig. & 0.000 & 0.000 & - & 0.000 \\
\hline Durbin-Watson & 1.93 & 1.91 & - & 1.93 \\
\hline
\end{tabular}

Notes: In all econometrics specifications, the dependent variable is the ratio of capital flight $(K F)$ to Gross Domestic Product $(G D P)$. The independent variables are as follows: $K F_{t-1}=$ capital flight for year $t-1 ; E D=$ external debt; GR $=$ real $G D P$ growth; $U N C=$ uncertainty; $F D I=$ net foreign direct investment; $R E E R=$ real effective exchange rate; $I N F=$ inflation rate; INR $=$ interest rate differentials; $O L S$ is the ordinary least squares model; $F E$ is the fixed effects model; $R E$ is the random effects model; $S U R$ is the seemingly unrelated regression model. $* * *, * * *$ indicate significance at the 1,5 and 10 per cent levels, respectively. Each cell contains the regression coefficient and the absolute value of the $t$-statistic in parentheses.

The results confirm that external borrowings provide the fuel and/or motive for capital flight, where the coefficient on the change in external debt $(E D)$ is positive and significant at the $1 \%$ level. In four models, the estimated coefficients of $E D$ range from approximately 95 to 98 per cent, which means that the majority of a dollar of external borrowing by MENA countries ended up as capital flight. The result suggests that governments are responsible in ensuring that the external borrowings benefit their economies and not that the funds end up enriching a few individuals (Beja, 2007). This finding is on the line of Ndikumana and Boyce (2002) for Sub Saharan African Countries and Beja (2007) for Indonesia, Malaysia, and Thailand and Chipalkatti and Rishi (2001) for India.

The results also indicate that the GDP growth rate is negatively related to capital flight: higher growth leads to less capital flight. In all regressions, the negative coefficient on the GDP growth rate is statistically significant at the $10 \%$ level. The result suggests the importance of sound macroeconomic management. Countries unable to improve economic growth, because of weak macroeconomic policies or inefficient economic sectors, will discourage investors. This can lead to conditions conducive to capital flight (see Beja, 2006). This result supports the empirical evidence provided by Boyce (1992), Chipalkatti and Rishi (2001), Quazi (2004), and Beji (2007).

Under four models, the coefficient of uncertainty (UN) variable is positive and significant at the $1 \%$ level. In line with what might have been expected, uncertainty appears to be an important determinant of capital flight. In order to reduce capital flight, governments of MENA countries should focus on stabilizing their macroeconomic environment because as long as economic policies and their impact on the real value of wealth are unclear, residents are likely to decide to take their money and run, since real returns on foreign assets are more clear and certain (see Hermes and Lensink, 2001).

The results confirm that net foreign direct investment (FDI) represents a motive for capital flight, where the coefficient on FDI is positive and significant at the $1 \%$ level. In four models, the estimated coefficients of $F D$ range from approximately 85 to 87 per cent, which means that the majority of a dollar of FDI inflow to MENA countries 
ended up as capital flight. The result suggests that governments should pay more attention to the FDI and insure that the FDI benefits their economies.

Finally, whichever regression model we use, the results for other independent variables, REER, INF, and INR, are insignificant, which means that the real effective exchange rate, inflation, and interest rate differential have no influence on the capital flight in MENA countries during the study period.

\section{CONCLUSIONS}

This study examines the determinants of capital flight using a sample of MENA countries during the period 1981 to 2008. Using four econometrics techniques (OLS, Fixed Effect, Random Effect, and SUR), our empirical results show the importance of certain domestic macroeconomic fundamentals in determining capital flight. The results of our empirical analysis reveal the existence of a significant relationship between capital flight on one hand and lag capital flight, external debt, direct foreign investment, GDP growth, and uncertainty, on the other.

The results of this study have clear policy implications. In order to reduce capital flight, policy makers in MENA countries should focus on stabilizing their economic and political environment. In particular, they should apply clear and accurate policies regard their external debt and foreign direct investment, as well as with respect to monetary policies, affecting interest rates. Such clear and stable policies reduce uncertainty over their policies and their impact on the real GDP growth and real value of wealth as perceived by different agencies, which will positively contribute to reducing the outflow of domestic capital (see Hermes and Lensink, 2001)

\section{AUTHOR INFORMATION}

Dr. Nedal A. Al-Fayoumi is professor of banking and finance and the director general of financial funds at the University of Jordan. He has received his Ph.D from the University of Wales, UK in 1999.Professor Al-Fayoumi published and refereed research papers in prestigious Banking and Finance journals. His main teaching and research interests lie in the capital markets based research, managerial finance, and banking. Recently, he won the prize of distinguished researcher from his university. E-mail: nfayoumi@ju.edu.jo. Corresponding author.

Dr. Marwan S. AlZoubi is a former dean of the institute of banking studies at the central bank of Jordan. He received his PhD from North Texas University, USA in 1994. His main research interests lie in the capital flight, banking stability and open market operations. E-mail: alzoubim@ibs.edu.jo

Dr. Bana M. Abuzayed is assistant Professor of Banking and Finance at Talal AbuGhazaleh Graduate School of Business Administration/ German Jordanian University. She earned her Ph.D. and MA in Banking and Finance from the University of Wales (UK). Her main teaching and research interests lie in the market-based accounting research, financial systems stability, financial integration and managerial finance issues. She has published and refereed a number of research papers in international journals. E-mail: bana.abzayed@ gju.edu.jo

\section{REFERENCES}

1. Alam M, Quazi R., (2003), "Determinants of capital flight: an econometric case study of Bangladesh", International Review of Applied Economics 17: 85-103.

2. Al-Fayoumi, N., Abuzayed, B., (2009), "Ownership structure and corporate financing", Applied Financial Economics, 19: 1975-1986.

3. Almounsor, A., (2008), "Capital flight accounting and welfare implications in the MENA region", Review of Middle East Economics and Finance, 4: 1-67.

4. Beja E., (2006), "Was capital fleeing Southeast Asia? Estimates from Indonesia, Malaysia, the Philippines, and Thailand". Asia Pacific Business Review, 12 (A3): 261-283.

5. Beja, E., (2007), "Brothers in distress: revolving capital flows of Indonesia, Malaysia, and Thailand", Journal of Asian Economics, 18: 904-914.

6. Brada, J., Kutan, A., Vukšić, G., (2009), "The costs of moving money across borders and the volume of capital flight: the case of Russia and other CIS countries". WP-EMG-28-2009, City University, UK. 
7. Buiter, H., Szegvari, I., (2002), “Capital flight and capital outflows from Russia, cause and cure”, London EBRD, Working Paper No. 73.

8. Bunkanwanicha, P., Gupta, J., Rokhim, R., (2008), "Debt and entrenchment: evidence from Thailand and Indonesia", European Journal of Operational Research 85: 1578-95.

9. Cerra, V., Rishi, M., Saxena, C., (2005), "Robbing the riches: capital flight, institutions, and instability" IMF Working Paper, WP/ 05/ 1999.

10. Cheung,Y., Qian, X., (2010), “Capital flight: China's experience. Review of Development Economics 14: 227-247.

11. Chipalkatti N., Rishi, M., (2001), "External debt and capital flight in the Indian economy. Oxford Development Studies 29: 31-44.

12. Cuddington, J ., (1986), "Capital Flight: Issues and Explanations". Princeton Studies in International Finance, Vol. 58, Princeton, NJ: Princeton University.

13. Fedderke, J., Liu, W., (2002), "Modelling the determinants of capital flows and capital flight: with an application to South African data from 1960 to 1995", Economic Modelling, 19: 419-444.

14. Harrigan, J., Mavrotas, G., and Yusop, Z., (2002), "The determinants of capital flight: a new approach", Journal of the Asia Pacific Economy 7: 203-241.

15. Hermes, N., Lensink, R., (2001), “Capital flight and the uncertainty of government policies”, Economics letters 71: 377-381.

16. Le Quan, V., Rishi, M., (2006), “Corruption and capital flight: an empirical assessment”, International Economic Journal 20: 523 - 540.

17. Lessard, L., Williamson, J., (1987), “Capital flight and the third world debt”, Washington, DC: Institute of International Economics.

18. Ljungwall, C., and Wang, Z., (2008), "Why is capital flowing out of China? China Economic Review: 19, 359-372.

19. Mckinnon, R., (1991), "The order of economic liberalization: financial control in the transition to a market economy Baltimore”, Johns Hopkins University Press.

20. Mikkelsen, J., (1991), "An econometric investigation of capital flight”, Applied Economics, 23: 73-85.

21. Moghadam, M., Samavati, H., and Dilts, D., (2003), "An examination of capital flight from East Asian emerging economies: paradise lost", Journal of Asia-Pacific Business, 5: 33-49.

22. Mohamed, S., Finnoff, F., (2004), "Capital flight from South Africa, 1980 to 2000", African Development and poverty Reduction: The Macro-Micro Linkage, Forum paper, South Africa.

23. Morgan Guaranty Trust Company (1986) LDC capital flight. World Financial Markets (March), 13-15.

24. Ndikumana, L., Boyce, J., (2008), "New estimates of capital flight from Sub-Saharan African countries: linkages with external borrowing and policy options", University of Massachusetts, Political Economy Research Institute, Working Paper, No. 166.

25. Ndikumana, L., Boyce, J., (2003), "Public debts and private assets: explaining capital flight from SubSaharan African countries' World Development, 31: 107-130.

26. Pesaran, M., Shin, Y., Smith, R., (2001), "Bounds testing approaches to the analysis of level relationships", Journal of Applied Econometrics, special issue in honor of J. D. Sargan on the theme 'Studies in Empirical Macroeconometrics,' edited by D. F. Hendry and M. H. Pesaran. 16: 289-326.

27. Ralhan, M., (2006), "Determinants of capital flows: a cross country analysis", Econometrics Working Paper EWP0601, Department of Economics, University of Victoria, Canada.

28. The World Bank, (1985), World development report. The World Bank, Washington, DC.

29. Vos, R., (1992), "Private foreign asset accumulation, not just capital flight: evidence from the Philippines. Journal of Development Studies 28: 500-537.

30. Wang, Z., Wang, S., Huang, T., (2009), "Re-estimation of capital flights from China: 1982-2005”, Applied Economics Letters, 16: 971-976.

31. Zheng, Y., Tang, K., (2009), "Rethinking the measurement of capital flight: an application to Asian economies", Journal of the Asia Pacific Economy, 14: 313-330. 
NOTES 